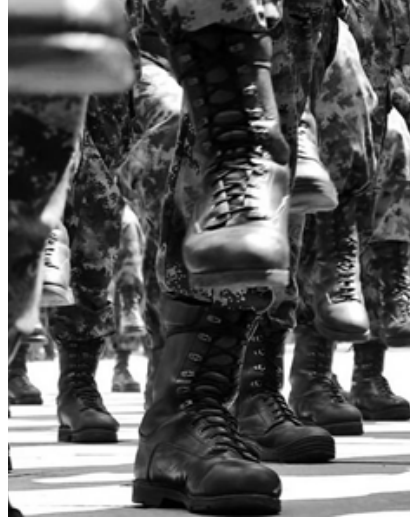

PC: videoblocks.com

\section{Transnational Carceral Capitalism in Xinjiang and Beyond}

\section{Gerald ROCHE}

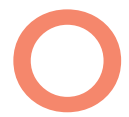

n 22 January, the innocuously-named 'Frontier Services Group' (FSG) announced plans to open a 'training centre' in Xinjiang, where approximately one million people are currently being held in concentration camps (Shepherd 2019). This announcement highlights a vital and underexplored element in the story of Xinjiang's campsthe role of private paramilitary companies and transnational circulations.

Frontier Services Group is a private security firm, run by Blackwater founder Erik Prince (Ciralsky 2009). And although Prince publically expressed surprise at the 22 January announcement, FSG was in fact already deeply embedded in Xinjiang well before then (Stevenson and Buckley 2019).

FSG first announced plans to open an office in Xinjiang in March 2017 (Fan 2017), and in November of that year, they appointed Lü Chaohai as Head of their northwest regional operations (Bloomberg 2019; FSG 2017). Previously, Lü was the Vice-president of the Xinjiang Construction and Production Corps, the paramilitary-cum-commercial organisation tasked by the Chinese Communist Party (CCP) with developing Xinjiang's economy.

Beyond these clear linkages between FSG and Xinjiang, other plausible but less obvious connections link the company to the region and its camps. For example, since acquiring a stake in Beijing's International Security and Defence College in May 2017, FSG has been working to train private anti-terrorism personnel in China (Martina 2017). And although no explicit links between the College and Xinjiang are apparent, its antiterrorist mandate makes these likely.

In addition to working within the People's Republic of China (PRC), Prince and FSG are also following China's commercial interests abroad. The company has unambiguously positioned itself as a security provider for the Belt and Road Initiative (BRI). For example, in December 2018, FSG obtained a license to operate in Cambodia, an enthusiastic supporter of the BRI, and a recent recipient of 600 million USD in aid from China (FSG 2018b; Mech 2019). And, as we will see below, FSG is also setting up in Myanmar. 
First of all, it makes

clear that we should be paying more attention to private, transnational actors-not just Prince and FSG, but also the entire private paramilitary industry. The Xinjiang camps are built and maintained not only by state colonialism, but also transnational carceral capitalism.
These connections highlight how not just FSG and Prince, but the private paramilitary industry more generally, act as conduits between state actors. So we should not be surprised to learn that while FSG works for China, Prince is simultaneously attempting to exert influence on US policy. In 2016, he addressed newly-elected President Trump in a South China Morning Post op-ed, advocating for the United States to become involved with the BRI (Prince 2016).

But Prince has closer ties to Trump than your average oped writer. In addition to having donated a quarter of a million dollars to Trump's presidential campaign, Prince is also the brother of the current US State Secretary of Education, Betsy DeVos (Kirsch 2018). It should not be surprising, then, that he has recently met with Trump to pitch the privatisation of US operations in Afghanistan and Syria (Hall 2019; Roston 2017). Tellingly, he refers to this strategy as an 'East India Company' approach.

So, Erik Prince is advocating for the United States to roll out mercantile colonialism from Afghanistan to Nigeria, while also helping train anti-terrorism personnel in the PRC, employing political elites from Xinjiang, and opening operations along the BRI. This entanglement of state and private interests across borders has important implications for how we think about, and act against, the Xinjiang camps.

First of all, it makes clear that we should be paying more attention to private, transnational actors-not just Prince and FSG, but also the entire private paramilitary industry. The Xinjiang camps are built and maintained not only by state colonialism, but also transnational carceral capitalism (Wang 2018). What other connections exist between Xinjiang and security providers from outside the PRC?

Understanding this is important because it will shed light on what techniques are being exchanged and circulated between carceral institutions around the world. This might provide insights into what is going on in Xinjiang when we have such limited access to the realities of the camps.

Researchers have already learnt much about the Xinjiang camps by tracing their evolution from trials elsewhere inside the PRC. Adrian Zenz and James Leibold (2017) have showed how securitisation techniques road-tested in Tibet are now applied in Xinjiang, and Sarah Cook (2019) has recently shown how the techniques of 'mental transformation' being used in Xinjiang were first tested on members of the Falun Gong. 
So, we should be asking, beyond sources within the PRC, what are the transnational precursors to the Xinjiang camps? What current models might the camps' architects be drawing on? What role might private security and logistic companies play in linking these diverse examples, and accelerating the circulation of carceral expertise?
But missing from this story of the internal circulation of methods and technologies of control within China is the exchange of these things transnationally. Take the camps themselves. We know that concentration camps as a carceral form were first deployed in Cuba by Spain during the Cuban War of Independence (1895-98) (Mühlhahn 2010). They were then developed through their global circulation and iterative tweaking by a variety of states across the twentieth century (Pitzer 2017).

So, we should be asking, beyond sources within the PRC, what are the transnational precursors to the Xinjiang camps? What current models might the camps' architects be drawing on? What role might private security and logistic companies play in linking these diverse examples, and accelerating the circulation of carceral expertise?

Given the way these technologies circulate transnationally, and considering FSG's role as a BRI private security force, we should be concerned with the possibility that camps might spread across borders. FSG has recently started advertising to recruit personnel in Myanmar, and its website lists news about the recent MoU between Myanmar and the PRC to establish a transnational economic corridor (FSG 2018a). This corridor starts in Yunnan, where FSG has an office, and ends in the Kyaukpyu Special Economic Zone in Rakhine state, the province where the Rohingya ethnic cleansing is being carried out. We need to worry about how PRC money and private paramilitary expertise might be used to 'help' nations on the BRI solve their domestic problems.

Beyond these concerns, the transnational privatisation of mass detention gives us two good reasons to be sceptical about the effectiveness of lobbying state actors to intervene in the Xinjiang camps. First, most major state players today have an interest in honing their carceral techniques and technologies, and private security firms enable liberal democracies to learn from authoritarian states, where the latitude for trial and error is much greater. Secondly, although the BRI has become a source of geopolitical friction, such divisions are worn away by the flow of transnational capital, and the commercial stakes associated with the BRI are vast. It seems unlikely that any states will work against their own political and economic interests to intervene in Xinjiang.

Rather than lobbying states, a more effective strategy would be to address the struggle against the Xinjiang concentration camps to actors that have no vested interests in the camps being maintained: anti-colonial, anti-capitalist, and prison abolitionist movements. 